\begin{tabular}{|l|l|l||}
\hline \multicolumn{2}{|c|}{ PublisherInfo } \\
\hline \hline PublisherName & $:$ & BioMed Central \\
\hline \hline PublisherLocation & $:$ & London \\
\hline \hline PublisherImprintName & $:$ & BioMed Central \\
\hline \hline
\end{tabular}

\title{
Estrogen receptor activity in vivo
}

\begin{tabular}{|l|l|l||}
\hline \multicolumn{2}{|c|}{ ArticleInfo } \\
\hline \hline ArticleID & $:$ & 4665 \\
\hline \hline ArticleDOI & $:$ & $10.1186 /$ gb-spotlight-20021224-01 \\
\hline \hline ArticleCitationID & $:$ & spotlight-20021224-01 \\
\hline \hline ArticleSequenceNumber & $:$ & 331 \\
\hline \hline ArticleCategory & $:$ & Research news \\
\hline ArticleFirstPage & $:$ & 1 \\
\hline \hline ArticleLastPage & $:$ & 2 \\
\hline \hline & $:$ & RegistrationDate : 2002-12-24 \\
ArticleHistory & $:$ & OnlineDate \\
\hline \hline ArticleCopyright & $:$ & BioMed Central Ltd2002-12-24 \\
\hline \hline ArticleGrants & $:$ & \\
\hline \hline ArticleContext & $:$ & 130593311 \\
\hline \hline
\end{tabular}




\section{Jonathan Weitzman}

Email: jonathanweitzman@hotmail.com

Estrogen receptors (ERs) are ligand-induced transcription factors. In an Advanced Online Publication in Nature Medicine Ciana et al. report their study of a transgenic mouse strain designed to follow ER activity in vivo (Nature Medicine, 16 December 2002, DOI:10.1038/nm809). The ERE-luc mice express a luciferase reporter gene under the control of an estrogen-responsive element, and the luciferase, can be monitored by injection of the substrate luciferine followed by bioluminescence measurements using a cooled charged device camera. A peak of luciferase activity was detected at proestrus in ovaries and liver, corresponding with high levels of circulating estradiol. Other tissues and non-reproductive organs had a peak at diestrus. Also, Ciana et al. found evidence for ER activity in immature mice before gonadal production. This model will be important for dissecting ER activation pathways that are dependent on, or independent of ligand, particularly in light of the use of estrogens in hormonereplacement therapies.

\section{References}

1. Nuclear receptor coactivators - an update

2. Nature Medicine, [http://www.nature.com/naturemedicine]

3. Engineering of a mouse for the in vivo profiling of estrogen receptor activity. 